\title{
Maximum Length Number
}

National Cancer Institute

\section{Source}

National Cancer Institute. Maximum Length Number. NCI Thesaurus. Code C42696.

Indicates the greatest number of characters permissible in a value. 